$\overline{\overline{\text { 論 }}} \overline{\overline{\text { 文 }}}$

農業気象 (J.Agr. Met.) 49 (2): 81-90, 1993

\title{
冬季の成木茶園における温度分布 と樹体の凍結・融解
}

\author{
高市益行 ${ }^{*}$. 米谷 力 ${ }^{* *}$ \\ $\left(\begin{array}{l}* \text { 大阪府立大学農学部農業気象環境学研究室 } \\ * * \text { 奈良県農業試験場茶業分場 }\end{array}\right)$
}

Temperature Distribution and Freeze-Thaw Process

of Mature Tea Plants in a Tea Garden in Winter

Masuyuki Takaichi* and Tsutomu Yonetani**

$\left(\begin{array}{c}* \text { Lab. of Agricultural and Environmental Meteorology, College of Agriculture, } \\ \text { University of Osaka Prefecture, Gakuen-cho, 1-1, Sakai, Osaka 593, Japan } \\ \text { **Tea Branch, Nara Prefectural Agricultural Experiment Station, }_{\text {Yatahara-cho Otsu 470-1, Nara 630-21, Japan }}\end{array}\right)$

The relationship between temperature distribution around a mature tea bush and its freezethaw process was studied in winter. The coldest parts of a bush in nighttime were the top or the lee shoulder for a horizontal plot and the down-slope side shoulder for the row across the contour line on a slope in many cases. Temperature difference $(\Delta T)$ between the bush top leaves $\left(T l_{\text {TOP }}\right)$ and air at $150 \mathrm{~cm}$ height $\left(T a_{150}\right)$ could be expressed as a following simple equation:

$$
\Delta T=T l_{\text {TOP }}-T a_{150}=A U_{150}^{-0.5} R n
$$

where $A$ : an empirical constant, $U_{150}$ : wind speed at $150 \mathrm{~cm}$ height, $R n$ : net radiation above tea bushes. Values of $A$ were $0.0320\left(\mathrm{~J}^{-1{ }^{\circ}} \mathrm{C} \mathrm{m}^{2.5} \mathrm{~s}^{0.5}\right)$ for the bush with few elongated shoots above the plucking table and 0.0227 for the one with many of them, respectively.

The times required for freeze to spread over the aboveground part of the bush were from about 20 to 90 minutes. The freezing of the bush top leaves were initiated nearly at the dewpoint temperatures around them $\left(T d e w_{\text {TOP }}\right)$ when $T d e w_{\text {TOP }}$ were about $-2^{\circ} \mathrm{C}$ to $-4^{\circ} \mathrm{C}$. For lower humidity $\left(\right.$ Tdew $\left._{\mathrm{TOP}}<-4^{\circ} \mathrm{C}\right)$, the freezing initiated without dew or frost formation on leaves. These results were almost the same as those of young tea plants reported previously.

The latest thawing of the bush was at the bottom trunk and this part occasionally kept frozen to the following nights. In daytime a situation that the bottom trunk was still in freeze while the bush top leaves were already thawed was observed. This status might increase the water deficit stress if there were high transpiration demands.

Among simple methods to estimate the initiation of the freezing, the ones using $T l_{\text {TOP }}$ and Tdew $w_{\text {TOP }}$ could make relatively good estimates with about 20-30 minutes of root mean square error for the samples.

Key words: Freezing temperature, Freezing injury, Tea plant, Leaf temperature.

キーワード：茶樹, 凍結温度, 凍結被害, 葉温 


\section{1. まえがき}

植物体に凍害・霜害が発生するには，その凍結が必須 条件である(Sakai and Larcher, 1987)。凍結開始の メカニズムに関する研究は多く, 凍結開始に影響する要 因として, 結露の有無(羽生ら, 1986 : 岡野ら, 1989), 永核活性細菌の状態(牧野, 1985: 馮ら, 1989：劉ら, 1991)などが報告されている。また，凍結が生じた場合 の被害程度は, 最低温度が同じでも, 凍結開始温度（山 中ら, 1982：Andrews et al., 1986)や倲結時の温度低 下速度 (原田・中山, 1961)，凍結の継続時間（北浦, 1967：鳥屋尾ら，1974）, 融解時の昇温速度（吉田・酒 井, 1967）などの要因により变化するてとが知られてい る。したがって, 凍害・霜害の被害要因の解析, 発生の 予測，防除法の検討などを行う際に，低温の程度だけで はなく, 上記の凍結一融解に関わる諸要因を考慮に入れ ればより詳細な検討が可能になると思われる。しかし， 野外の植物体の凍結一融解汇関する資料は一般に不足し て抢り，茶樹についてもその実態については不明な点が 多い。

著者らは前報（高市・米谷，1990）で, 幼木茶園にお ける冬季・夜間の樹体の温度分布の特徽, 凍結の実態, 気象条件と涷結開始温度の関係などについて報告した。 本研究では, 成木園において, 前報之同様に, 冬季・夜 間の株周辺の温度分布の特徵を明らかにするための観測 を実施し, 気象条件之凍結一融解之の関係について解析 を行った。また，樹体の凍結一融解を気象条件から推定 する方法について若干の考察を行ったので，それらの結 果を報告する。

\section{2. 観測場所および方法}

観測は, 1987 年と 1989 年の 1-2 月に奈良市矢田原 町の奈良県農業試験場茶業分場内の茶園（海抜約 $420 \mathrm{~m}$, 品種“やぶきた”, 成木園, ほぼ水平な区画に植栽, 南 北うね，うね間 $1.5 \mathrm{~m}$ )で実施した。また，傾斜地の株周 辺の温度分布を調べるため, 1990 年 3 月に奈良県添上 郡月ヶ瀬村の造成茶園（通称エンガ団地，円錐丘状，海 抜 355-385 m, うね間 $1.5 \mathrm{~m}$ ，品種“やぶきた”， Takaichi (1989) 参照)で観測を行った。

観测 I として, 1987 年に株周辺の詳細な温度分布の 把握に重点を置いた観測を行った。供試園（樹齢 21 年, 二番茶摘採後放任）の中央付近で，う和間地表から高さ $150 \mathrm{~cm}$ までの範囲の株の周辺・内部に気温センサー(筒 の直径約 $10 \mathrm{~mm}$, 熱電対は線径 $0.1 \mathrm{~mm}$ の JIS-T型)を 多数配置し, 数 $\mathrm{m}$ 離れた場所からエアーポンプで吸引し て気温を測定した。株頂部で天空に露出した 5 枚の葉を
選び，裏面ほぼ中央部に 線径 $0.1 \mathrm{~mm}$ の熱電対を貼付け て葉温を測定した。地温 $(1 \mathrm{~cm}, 10 \mathrm{~cm})$ の測定には線径 $0.3 \mathrm{~mm}$ の熱電対を用いた。乙れらの気温・葉温・地温と アイスジャーとの温度差に対応する出力電圧を, 手動切 替スイッチ(約 2 秒毎に各測定点を切替え)を介してペン レコーダに記録し，4回反復した平均值を解析に使用し た。また, 高さ $150 \mathrm{~cm}$ で純放射量 $R n$ を純放射計 (英弘 精機, $\mathrm{CN}-1$ ) で, 風速 $U_{150}$ を無指向性熱線風速計（日 本カノマックス社model 6071) で測定し，5分間の平均 值を使用した。

観測 II として，樹体の倲結一融解の把握に重点を置い た観測を 1989 年に行った (Fig. 1)。供試園(樹齢 23 年, 二番茶摘採後放任) のほぼ中央で, 地中 $10 \mathrm{~cm}$ から高さ $150 \mathrm{~cm}$ までの範囲の気温・地温の分布を観測 I と同様 の熱電対センサーで測定した。また，枝の中に細孔をあ けて熱電対 (線径 $0.1 \mathrm{~mm}$ JIS-T型)を挿入して茎温を測 定した(深さ約 $2 \mathrm{~mm}$ ，枝の直径が $4 \mathrm{~mm}$ 以下の細い枝で はその中心部)。株の頂部(摘採面の中央) とその両側の 肩部(株頂部之裾部の中間の位置)で, 天空に露出した葉 を各 3 枚選び，葉温を測定した。 水蒸気圧 $E a$ は高さ $150 \mathrm{~cm}$ 己株頂部付近 (高さ約 $100 \mathrm{~cm}$ ) で熱電対通風乾湿 計によって測定した。その他，地上 $150 \mathrm{~cm}$ で純放射量 $R n$ を純放射計 (英弘精機, $\mathrm{CN}-11$ ) で，風速 $U_{150}$ を熱 線風速計(前掲)で測定した。枝の温度と葉一気温差は, ハイブリッドレコーダ(横河電機 3087 型， 5 秒毎の打点 記録) とペンレコーダ(横河電機 3056 型, 連続記録) 亿記 録した。気温, 地温, $R n, U_{150}$ は, データロガー(江藤 電機, サーモダック E)を用いて 10 秒毎に計測し，その

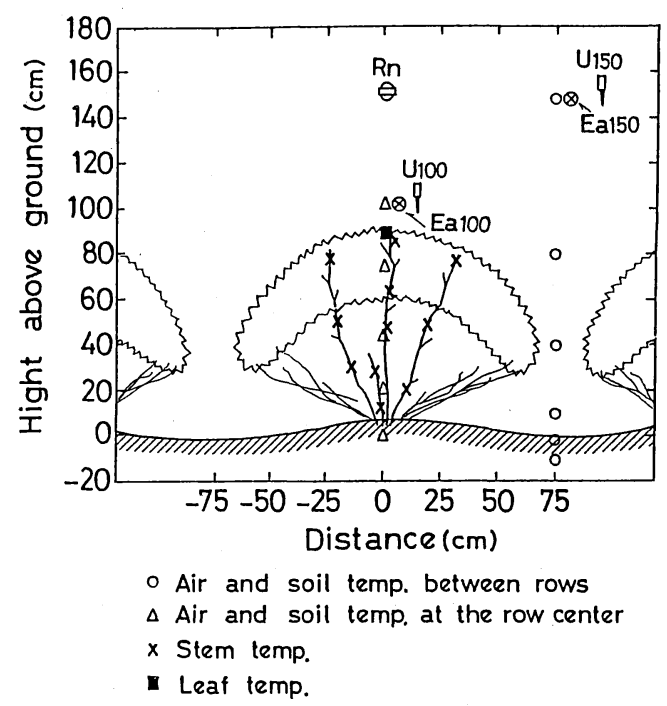

Fig. 1. Arrangement of each sensor around a mature tea bush in observation II (1989). 
4 分間平均值をパーソナルコンピュータの磁気ディスク に収録した。

枝や葉の凍結開始は，前報（高市・米谷，1990）之同 様に, その部位の荃温・葉温の一時的な上昇によって判 定した。また, 融解中の部位では, 他の部位が順調に昇 温していても $0{ }^{\circ} \mathrm{C}$ 付近で温度がしばらく一定になる現象 が見られるので，それによって融解開始時刻・終了時刻 を判定した。

また, 傾斜地茶園における株周辺の温度分布の観測で は (観測 III)，斜面の中腹 (斜面長約 $200 \mathrm{~m}$ ，上端から約 $50 \mathrm{~m}$ の地点，傾斜角約 11 度）で，等高線に添ったうね (以下では横うねと記す)について観測を行った。気温, 地温, $R n, U_{150}$ については前掲のセンサー, データロガ 一を用いて計測・収録し，それらの 5 分間平均值を解析 に使用した。

\section{3. 観測結果および考察}

\section{1 冬季・夜間の成木園の株周辺の温度分布の} 特徵

水平な場所に植栽された株について，その周辺の夜間 の気温・地温の分布の例を Fig. 2 亿示す (A : 等温線図, $\mathrm{B}$ ：鉛直プロファイル)。乙の時刻では純放射量 $R n$ と風 速 $U_{150}$ はそれぞれ- $49 \mathrm{~W} / \mathrm{m}^{2}, 0.7 \mathrm{~m} / \mathrm{s}$ で, 株面付近の 気温が最も低温となり, 株内部の気温は土壌の高温の影 響のためにやや高くなった。土壤表層の温度は，うね間 では天空との放射交換により株の直下の表層土壌よりも
低温である。高さ $150 \mathrm{~cm}$ 気温と株頂部の摘採面直上の 気温 $\left(T a_{\mathrm{TOP}}\right)$ との間には約 $2{ }^{\circ} \mathrm{C}$ 差が生じている。風向 はうねに沿う方向で，樹体周辺の気温で最も低温になる 位置は頂部の摘採面ほぼ中央になった。

このような株面の温度分布は気流に大きく影響される ので, 株頂部気温 ( $T a_{\mathrm{TOP}}$ ) と両肩部 (株面の頂部中央之 裾部との中間の位置)の気温 $\left(T a_{\mathrm{S}}\right)$ との差が, 気流の状 態によってどのように変化するのかを調べた(Fig. 3)。 図中の各点は，観測日夜間の毎正時のデータのうち，株 面上の $R n$ がー $50 \mathrm{~W} / \mathrm{m}^{2}$ の場合のみをプロットしたもの である。

気流がうね方向に沿う場合 (うね方向士23，Fig. 3A), 両肩部気温と株頂部気温の間にあまり大きな差は生じな いが, $U_{150}$ が $0.3 \mathrm{~m} / \mathrm{s}$ 以下の弱い風の場合は $U_{150}$ が小さ くなるにつれて肩部よりも頂部の方が低温になってくる ような傾向が見られる。

一方，気流がうねを横切る方向の場合（うねの直角方 向 $\pm 45^{\circ}$, Fig. 3 B ), 両肩部と株頂部との気温差はうね に沿う風向の場合よりあバラッキが大きくなる。風速 $U_{150}$ が $0.3-0.8 \mathrm{~m} / \mathrm{s}$ 程度のときは, 頂部の方が両肩部よ りも高温になる傾向が見られる。 $U_{150}$ が $0.4 \mathrm{~m} / \mathrm{s}$ 以下で 弱いときは，風下側肩部の方が風上側よりもわずかに低 温になった。乙のように，風上側肩部，株頂部，風下側 肩部の順序に低くなる状態は，高橋ら (1961) の観測結 果の中にあ認められる。また， $U_{150}$ が $1 \mathrm{~m} / \mathrm{s}$ 以上のかな り強風の場合には, 風上側や頂部が風下側より低温にな
(A)

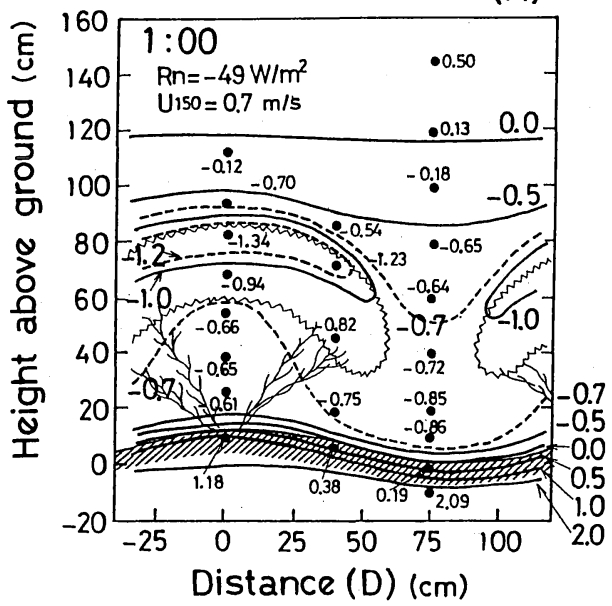

(B)

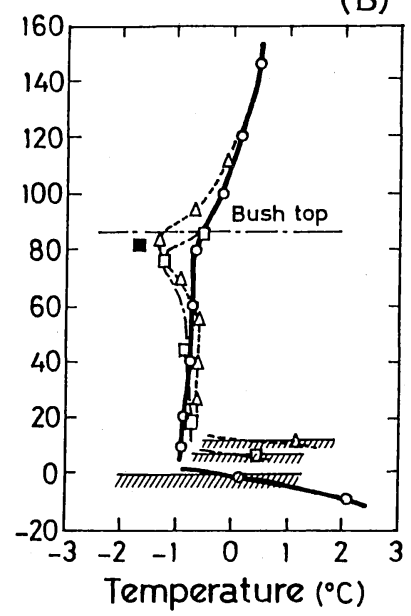

- Temp. protile at $D=75 \mathrm{~cm}$

- - $\triangle---$ Temp. profile at $D=0 \mathrm{~cm}$ (row center)

- ----- Temp. profile at $D=0 \mathrm{~cm}$

Leaf temp. at the top of bush

Fig. 2. An example of temperature distribution around a mature tea bush planted on a horizontal plot (Jan. 23, 1987).

(A) Isothermals, (B) Vertical profiles. 

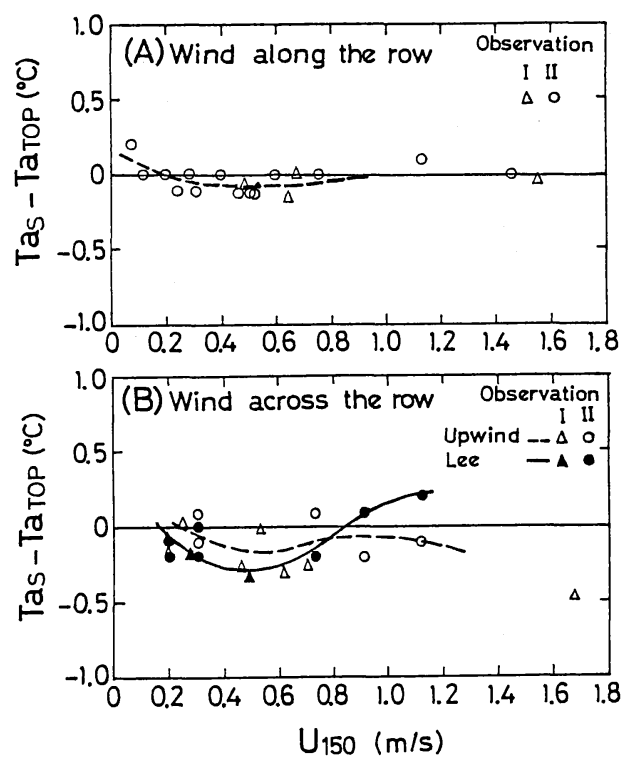

Fig. 3. Changes in the air temperature difference between bush top $\left(T a_{\text {TOP }}\right)$ and shoulders $\left(T a_{\mathrm{S}}\right)$ with wind conditions. (A) wind along the row, (B) wind across the row (Observation I: $1 / 22,1987$, II: $1 / 27,1 / 30$ and $2 / 3,1989)$.
り，乙れは通常考えられる分布とは逆になっている。本 報告とは別の赤外線熱映像カメラ（日本電子, サーモグ ラフィ 3010)による株面葉温の分布の観察の際にむ, 風 速が強い場合に風上側肩部が風下側よりも低温になる現 象が見られた。乙の理由として, 強風による葉面からの 蒸散(あるいは凍結葉からの脱水)墸えられるが，ての 点についてはさらに詳しく検討する必要がある。

なお, 葉とその近傍の温度差 (葉一気温差) については, $R n$ がー70 から $-80 \mathrm{~W} / \mathrm{m}^{2}, U_{150}$ が 0.3 から $0.5 \mathrm{~m} / \mathrm{s}$ 程 度の条件に扔いて, 株頂部の天空に露出した葉で 1.5 $2.0^{\circ} \mathrm{C}$, 摘採面より内部の深さ約 $15 \mathrm{~cm}$ の位置では $0.3-$ $0.5^{\circ} \mathrm{C}$ となった。深さ $30 \mathrm{~cm}$ の位置では, 葉一気温差は $R n$ に関わらず $0.2^{\circ} \mathrm{C}$ 以になってほとんど変化しないと いう結果が得られた。

以上は水平な区画に植栽された株についての結果であ るが，次に，傾斜面の等高線植え(横うね)の株周辺扔よ び内部の気温・地温分布の例を示す (Fig. 4)。乙の時刻 のRnは-76 W/ $\mathrm{m}^{2}, U_{150}$ は $0.3 \mathrm{~m} / \mathrm{s}$ で, 比較的強い放 射冷却が生じていた。風は山側から谷へ流下し，うねを 横切る方向であった。摘採面の中央では比較的高温で, 気温が最低温となる位置は気流の遮られる谷側の肩部か ら裾部にかけての部位になった。ての位置の気温と株頂 部気温との差は約 $1.5^{\circ} \mathrm{C}$ であった。山側の裾部は, 山側 隣のうねの株面が低温であり, 気流も遮るので, 株頂部 よりも低温になった。

傾斜地茶園の晚霜害において被害が激甚でない場合に
(A)

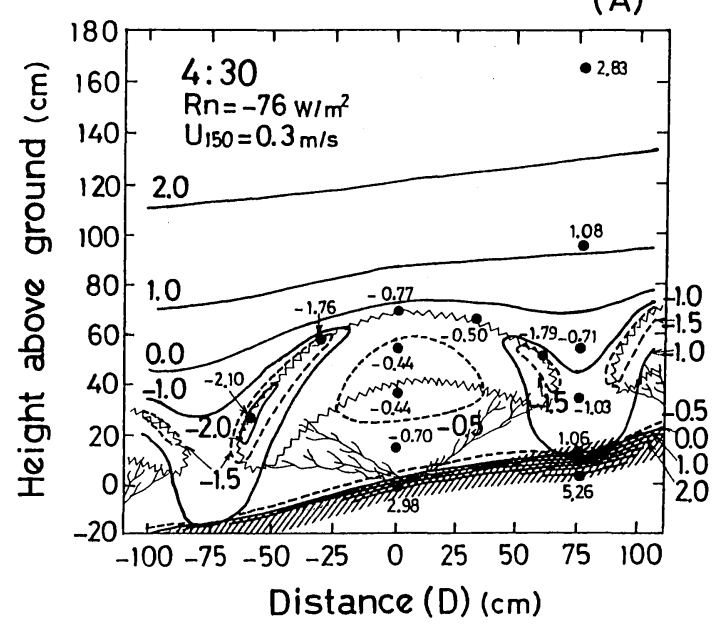

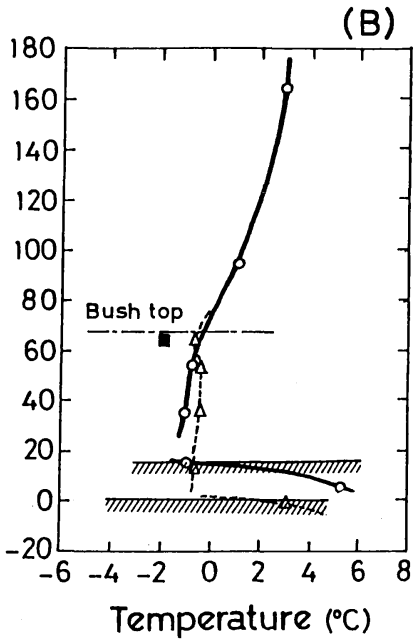

$\longrightarrow$ temp. profile at $D=75 \mathrm{~cm}$ -- temp. profile at $D=0 \mathrm{~cm}$

- leaf temp. at the top of bush

Fig. 4. An example of temperature distribution around a mature tea bush planted on a slope along the contour line (March 21, 1990).

(A) Isothermals, (B) Vertical profiles. 
は, 株面の谷側が被害を受け山側は無被害であったり, その逆であったり，また，株の頂部だけが筋状に被害を 受けたりする。乙れは, Fig. 3 亿示したような温度分布 と気流との関係によって生じたものと考えられる。今回 の傾斜面横うねの温度観測結果では, 株面直上の気温に は株面山側の高温部之谷側の低温部之の間で約 $1.5{ }^{\circ} \mathrm{C}$ の 差が見られた。Rnや $U_{150}$ が同程度であれば, 晚霜期夜 間であ同程度の温度差が予想され，乙の差は被害発生温 度付近では, 被害の有無を分けるのに十分な大きさであ る。

\section{2 株面温度 (株頂部葉温) と高さ $150 \mathrm{~cm}$ 気 温との関係}

凍害・霜害を対象にする場合, 被害と直接関わるのは 株面の葉温である。乙こでは, 水平な場所に植栽された うねについて, 高さ $150 \mathrm{~cm}$ 気温 $\left(T a_{150}\right)$ と株頂部葉温 $\left(T l_{\mathrm{TOP}}\right)$ との間の差が気象条件によってどの程度になる のかを調べた。 $T l_{\mathrm{TOP}}$ は株面温度のほぼ最低值となるが, うねを横切る弱い風が吹く夜には $\left(0.2 \leqq U_{150}<1 \mathrm{~m} / \mathrm{s}\right.$ 程 度), 最低值より高くなる場合あある (Fig. 3 参照)。 $T l_{\mathrm{TOP}}$ と $T a_{150}$ との差 $\Delta T$ 之, 純放射量 $(R n)$, 風速 $\left(U_{150}\right)$ との関係を表現する式として, 前報 (高市・米谷, 1990 ) と同様に, $\Delta T$ が $R n$ に比例し $U_{150}$ の 0.5 乗に反 比例する形を用いた。すなわち，

$$
\Delta T=A \cdot U_{150}^{-0.5} \cdot R n
$$

乙てでは係数 $A$ は定数として扱った。夜間 (20:0006:00）の毎正時の観測データを用いて係数 $A$ を最小自 乗法によって求めた結果, 観測 I では $0.0320\left(\mathrm{~J}^{-1} ・{ }^{\circ} \mathrm{C}\right.$ ・ $\mathrm{m}^{2.5} ・ \mathrm{~s}^{0.5}$ ) (デー夕範囲 : $0.2 \leqq U_{150}<1.9 \mathrm{~m} / \mathrm{s}, \quad-85 \leqq$ $R n<-1 \mathrm{~W} / \mathrm{m}^{2}$ ), 観測 II では 0.0227 (デー夕範囲 : 0.2 $\left.\leqq U_{150}<1.8 \mathrm{~m} / \mathrm{s}, \quad-89 \leqq R n<-4 \mathrm{~W} / \mathrm{m}^{2}\right)$ となった。 観測 I (1987年)と II (1989年)の株面の状態を比較する 之, 両者とも二番茶摘採後に放任したものであるが, 刈 取り時期やその後の管理, 気象条件の違いなどのため, 株面の突出枝の状態が大きく異なった(1987 年：ほとん どなし，1989 年： $20 \mathrm{~cm}$ 四方の範囲に長さ $15-25 \mathrm{~cm}$ のむのが $5-8$ 本程度伸長)。係数 $A$ (株面上の温度勾配 と $R n, U_{150}$ との関係) が観測 I とII間でかなり異なっ た理由としては, 観測期間の気層の安定度や土袞水分条 件の違いなどあ考えられるが, 株面の突出枝の状態が最 あ大きく影響しているあのと推察される。

Fig. 5 は, 係数 $A$ の算出の際に用いたデー夕について, $\Delta T$ の計算值と実測值を比較したものである。観測 I, II とも, 多くのデータで計算值と実測值との差は $\pm 1^{\circ} \mathrm{C}$ 以内であるが，最大では $1.5^{\circ} \mathrm{C}$ 程度になった。両者の間 の相関係数は, 観測 I, II それぞれ $0.842,0.844$ であまり 高くはないが，(1)式が $\Delta T$ とRn, $U_{150}$ との抢招まかな

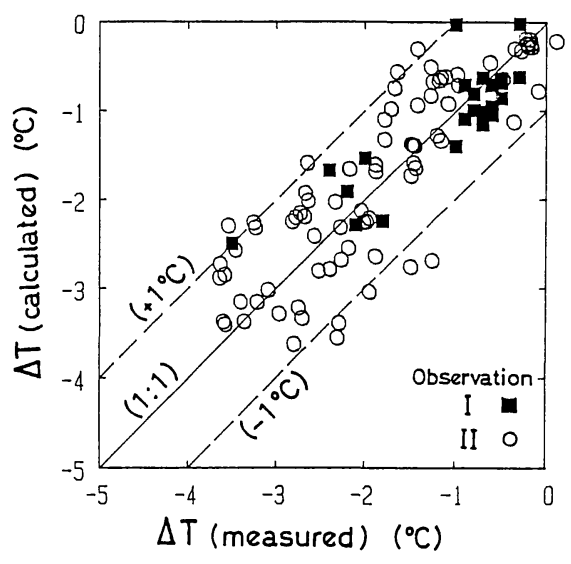

Fig. 5. Relationships between $\Delta T$ (measured) and $\Delta T$ (calculated) using equation (1). $\left(\Delta T=T l_{\mathrm{TOP}}-T a_{150}\right)$

関係を表現する 1 つの方法として利用できると思われる。 観測 I, II の係数を用いると, 晴れて風が弱い条件である $R n=-90 \mathrm{~W} / \mathrm{m}^{2}, U_{150}=0.3 \mathrm{~m} / \mathrm{s}$ の場合, $\Delta T$ は株面に 突出枝のない状態では約 $-4{ }^{\circ} \mathrm{C}$, 株面に突出枝がある状 態では約ー $5.5{ }^{\circ} \mathrm{C}$ になるととを示している。

観測現地では，寒害を軽減するため，秋整枝を行わず， 突出枝を延ばして越冬させる管理方法が一部で取られて いる。本研究の係数 $A$ の違いは, 乙の管理方法の葉温へ の効果を表わしているむのと考えられ，高橋ら (1961) による, 自然樹形で枝条を伸ばす手摘み園の方が弧状仕 立のハサミ摘み園よりも葉温が高温になり凍霜害を受け にくいとする考え方を支持している。

また, 高市・米谷 (1990) では, しきわらが施された 幼木について, 高さ $35 \mathrm{~cm}$ 葉温' $\left(T l_{35}\right)$ と $T a_{150}$ との差に 関する係数 $A$ の值として 0.0238 を報告した。 $R n, U_{150}$ が同じであれば, 突出枝が多い場合には成木の株頂部葉 温は $T l_{35}$ とほぼ同程度になり, 突出枝がなく摘採面がそ のままの成木では頂部葉温は $T l_{35}$ よりも低くなるととが 推測される。

\section{3 成木樹体の凍結開始温度と気象条件との関} 係

Fig. 6 亿，成木の枝の各部位の涷結開始時刻(図B)之 その時刻頃の株周辺の温度プロファイル(図A)の例を示 す。温度分布の形は, Fig. 2 と同様に夜間の放射冷却時 に一般的にみられる形である。乙の図では株元はまだ東 結開始前であるが, その温度は既に- $1{ }^{\circ} \mathrm{C}$ 以下に過冷却 しており, 地上部全体が涷結可能な状態になっていたて とを示している。

各部位の涷結開始時刻は, 枝条 A や Cでは株面が早く 内部は遅く, 枝条 $\mathrm{B}$ では逆に株元が早く表層部は遅かっ 
(A)

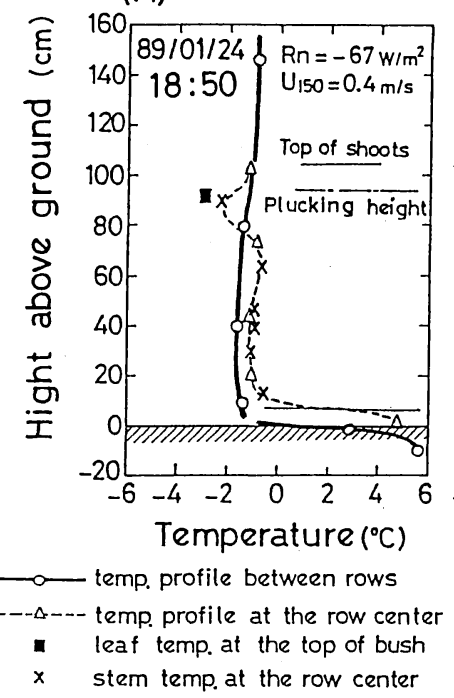

(B)

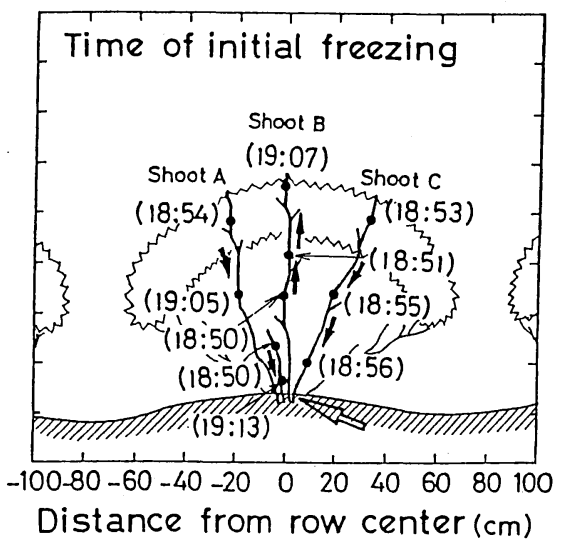

Fig. 6. An example of vertical temperature profiles (A) and time of freeze initiation at each part (B) of a mature tea plant (Jan. 24, 1989). Solid arrows indicate the directions of freeze spreading.

た。との日の樹体の凍結が最む早かったのは中央部の 18:50で株元の凍結はその 23 分後であった。てのよう な樹体内の涷結の開始・移行方向や地上部全体に凍結が 波及する時間は，前報の幼木の場合と同様に日ごとに異 なった。冬季の成木では，凍結が樹体の一部で検知され てから株元に伝わるまで数十分程度で伝わって，凍結部 之非凍結部の境界は幼木之同様に株元の地際部になるこ とが多かった。

葉層では非常に多数の枝条が分岐しているので，凍結 が樹体地上部全体に波及する時間が比較的短い(20-30 程度）夜については，今回の凍結測定点だけでは樹体で 最初に凍結を開始する部位は確定できなかった。しかし， 温度低下の緩やかな夜には，葉首の一部だけが一旦凍結 し，その後は温度低下につれて株元の方へゆっくり進行 していく例も見られた。乙れらのてとから，樹体の凍結 が最初に始まる部位は，一般に，株面表層部の複数箇所 であると推察される。

次に，株頂部の葉について，凍結開始時の葉温とその周 囲の露点温度との関係について調べ，幼木の高さ $h$ が 35 $\mathrm{cm}$ の葉（葉温が最低温を示す部位：○および $\triangle$ ) と比較 した (Fig. 7)。記号が成木のデータで，各プロットは 天空に露出した 3 枚の葉の平均值である。葉面近くの露 点温度が測定できたのは 7 例で，乙れらは幼木のプロッ 卜と同様に分布して打り，樹体で最も低温とみなせる部 位における凍結開始温度と露点温度の関係は，幼木と成 木の間で大差はないようである。乙の関係を簡単に表現

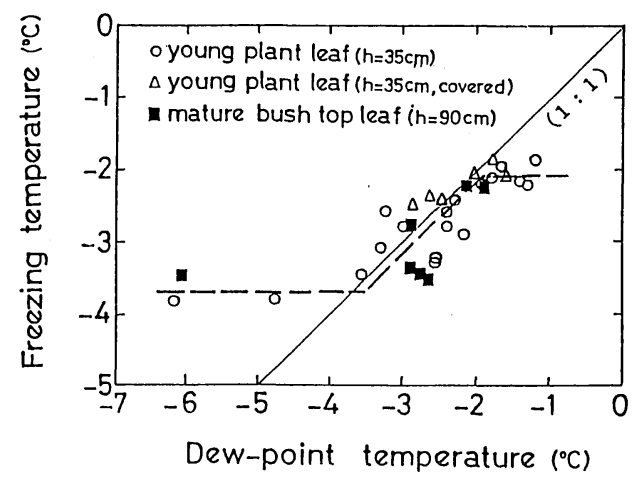

Fig. 7. Relationships between the freezing temperature of the bush top leaves and the dew-point temperature around them.

$(O$ : young plant leaves $(h=35 \mathrm{~cm}), \triangle$ : young plant leaves $(h=35 \mathrm{~cm})$, covered with black cheese-cloth, : mature plant leaves $(h=90 \mathrm{~cm})$ ).

すると以下のようになると考えられる。（1）葉温が約一 $2{ }^{\circ} \mathrm{C}$ 以下になるまでは結露があってあ凍結しない，（2） 露点が約 $-2{ }^{\circ} \mathrm{C}$ から約 $-4{ }^{\circ} \mathrm{C}$ の場合には, 葉温が露点温度 付近になると凍結を始める，（3）露点が約 $-4{ }^{\circ} \mathrm{C}$ 以下の 非常に乾燥している場合には, 葉面には結露・結霜がな くても葉温が $-4{ }^{\circ} \mathrm{C}$ 付近で涷結を開始する，ということ である。なお，図中の折れ線は，3.5 節で涷結開始を推 定する際们利用した関係である。 
植物体の凍結開始は偶発的で, 室内実験の同一の条件 で屯凍結開始温度はかなりの幅になることが知られてい る(羽生ら, 1986 ：岡野ら, 1989)。今回の凍結開始時の 葉温は約 $-2{ }^{\circ} \mathrm{C}$ から $-4{ }^{\circ} \mathrm{C}$ という比較的高く狭い範囲にな った。体類の凍結に関しては, Andrews et al. (1986) はモモの枝について，供試サンプルが大きくなると凍結 開始温度が高くなるてとを指摘している。また, Ashworth et al. (1985) は晚霜期の野外のネクタリン樹の枝につ いて $0.5^{\circ} \mathrm{C}$ からー $2.6^{\circ} \mathrm{C}$ というかなり高い凍結開始温度 を報告している。今回の茶樹でも凍結開始時の枝の温度 はほぼ同程度であった。鈴木ら（1985）による切り枝を 用いた室内実験 (2月で- $11{ }^{\circ} \mathrm{C}$ 程度) と比較して, 野外で の茶樹の凍結開始の温度範囲がかなり高く狭い範囲に集 まるのは, 凍結可能な過冷却状態にある枝条が多数存在 して速結の機会が多く, また, 樹体の一ケ所で始まった 凍結が過冷却している樹体に急速に伝わるためと考えら れる。

牧野 (1985) は静岡県において, 野外の茶芽の水核活 性細菌の季節変化を調へ，その細菌の永核形成の最高温 度は $-2^{\circ} \mathrm{C}$ で平均形成温度は $-2.7^{\circ} \mathrm{C}$ であったてとを報告 している。本研究における露点が約 $-4{ }^{\circ} \mathrm{C}$ 以上の条件に ついて, 葉温が露点温度付近で涷結を開始したのは, 株 面の葉面で生じた結露が涷結する (凍露), あるいは昇華 による結霜が生じたりして, その植水作用によって葉内 が東結を始めたと考えられる。Anderson et al. (1987) はモモの枝の内部に水核活性細菌之同等の高い水核活性 をむつ物質が存在するととを示唆しており，ての物質が 乾燥した日の茶樹の凍結の下限值を葉温でー $4^{\circ} \mathrm{C}$ (枝の温 度で約 -2 から $\left.-3^{\circ} \mathrm{C}\right)$ 程度に規定している可能性がある。 本研究の茶樹成木の凍結開始のデー夕は, 而凍性が最 あ高い時期についてである(築瀬ら，1974）。晚霜期の葉 の凍結開始温度については, 鈴木ら (1985) は室内実験 で, 新葉は成葉より高い温度で凍結を開始することを報 告しており, 野外においても新葉の凍結開始温度は今回 の結果より高くなって, さらに狭い温度範囲で涷結が始 まる可能性がある。また, 劉ら (1991) は氷核活性細菌 は高温で経過すると凍結核活性を失うことを報告してお り, 晚霜期の凍結開始の実態の解明が望まれる。

\section{4 成木樹体の融解の特徵と気象条件}

Fig. 8 亿, 融解時の株周辺の温度分布の例を示す。図 $\mathrm{A}$ は株頂部の枝（直径 $2.4 \mathrm{~mm}$ ) が融解を開始した時刻の 温度分布で, 株頂部の葉身は既に融解した部分とまだ東 結した部分が混在する状態で, 樹体の最低温度の部位は 株元になっている。乙の株頂部の枝は, 融解の開始から 終了までに11分を要した。図B 樹幹部の枝 (值径 $19.4 \mathrm{~mm}$ ) の融解が完了した時刻の温

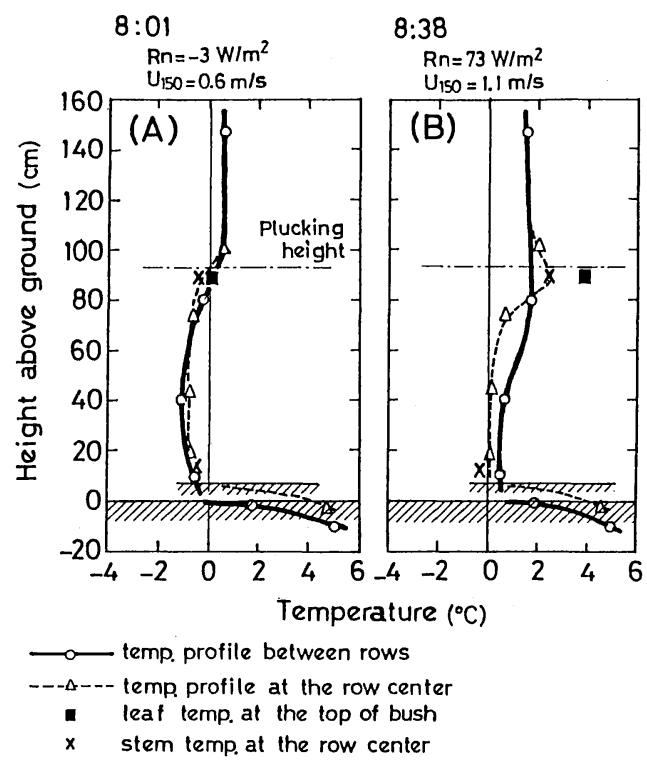

Fig. 8. An example of temperature distribution at the thawing of a mature tea plant in a clear morning (Jan. 22, 1989).

(A) At the start of thawing at the top stem.

(B) At the end of thawing at the bottom trunk.

度分布である。株元の融解は株面より大きく遅れ, 株元 が融解を終えた時には葉身の温度は約 $4{ }^{\circ} \mathrm{C}$ なっている。 この日の株元の枝の融解は開始から終了までに 25 分を 要した。株元が融解終了頃の温度分布は, 高さ約 $20 \mathrm{~cm}$ 以下の地面に近いところでは, 地中温度が高く, 地際部 の温度が最低で夜間の温度分布の特徵が残っているが, 株面では日射も強まっているので, 葉温が高い昼間の分 布形になっている。

Table 1 亿, 株頂部之株元樹幹部の 2 䇢所の枝につい $\tau$, 最低気温発現時刻 $\left(t_{\min }\right)$ の気象条件, そして樹幹 部の融解が終了した時刻 ( $\left.t_{\text {thaw }}\right)$ の気象条件を示した。 株元樹幹部の融解所要時間 $\left(P_{\text {thaw }}\right)$ は, 幼木では数分程 度で短いが, 成木では非常に時間がかかり，1月25日， 1月 30 日, 1 月 31 日では表層部が融解しても地際では さらに2-3 時間後に融解が終了した。また，1月28日, 29 日，2月 4 日のように, 昼間の気温上昇が小さいとき には，樹幹部は凍結したまま翌日あるいは翌々日まで 続く場合ああった。てれらのうち，1月29日，2月4日 では株面の葉層は昼間には融解していたが，乙のような 状態は地下からの水分移動が制限されているので, 特に 乾燥・強風条件下では水分欠乏のストレスが促進される と思われる。

最低気温が低い場合には，株元における凍結した水分 
Table 1 Micrometeorological conditions at the minimum temperature occurrence and at the completion of thawing at tea bush bottom trunk $(1 / 21-2 / 4,1989)$.

\begin{tabular}{|c|c|c|c|c|c|c|c|c|c|c|c|c|c|c|}
\hline \multirow[b]{2}{*}{$\begin{array}{l}\text { Date } \\
1989\end{array}$} & \multicolumn{6}{|c|}{ At Minimum Temperature Occurrence } & \multicolumn{8}{|c|}{ At Completion of Thawing of Bottom Trunk } \\
\hline & $\begin{array}{c}t_{\min } \\
(\mathrm{JST})\end{array}$ & $\begin{array}{c}R n \\
\left(\mathrm{~W} / \mathrm{m}^{2}\right)\end{array}$ & $\begin{array}{c}U_{150} \\
(\mathrm{~m} / \mathrm{s})\end{array}$ & $\begin{array}{l}T a_{150} \\
(\mathrm{C})\end{array}$ & $\begin{array}{c}T l_{\text {TOP }} \\
(\mathrm{C})\end{array}$ & $\begin{array}{l}T_{\text {BOT }} \\
\left({ }^{\circ} \mathrm{C}\right)\end{array}$ & Date & $\begin{array}{l}t_{\text {thaw }} \\
\text { (JST) }\end{array}$ & $\begin{array}{l}P_{\text {thaw }} \\
\text { (min) }\end{array}$ & $\begin{array}{c}R n \\
\left(\mathrm{~W} / \mathrm{m}^{2}\right)\end{array}$ & $\begin{array}{c}U_{150} \\
(\mathrm{~m} / \mathrm{s})\end{array}$ & $\begin{array}{l}T a_{150} \\
(\mathrm{C})\end{array}$ & $\begin{array}{c}T l_{\text {TOP }} \\
\left({ }^{(\mathrm{C})}\right.\end{array}$ & $\begin{array}{l}T_{\text {BOT }} \\
\left({ }^{\mathrm{C}}\right)\end{array}$ \\
\hline $1 / 22$ & $7: 30$ & -60.0 & 0.54 & -1.8 & -3.3 & -0.8 & $1 / 22$ & $8: 40$ & 25 & 72.9 & 0.75 & 1.6 & 3.8 & -0.2 \\
\hline $1 / 25$ & $7: 05$ & -57.1 & 0.38 & -4.6 & -7.4 & -5.0 & $1 / 25$ & $11: 00$ & 77 & 381.4 & 1.04 & 5.7 & 7.2 & 0.2 \\
\hline $1 / 26$ & $1: 00$ & -70.0 & 0.22 & -2.1 & -4.4 & -1.3 & $1 / 26$ & $8: 10$ & 197 & 18.6 & 1.36 & 3.5 & 3.4 & 0.2 \\
\hline $1 / 28$ & $7: 30$ & -57.9 & 1.26 & -3.9 & -4.9 & -2.9 & $1 / 28$ & \multicolumn{7}{|c|}{ (Freeze continued, $\left.T a_{150 \max }=-1.1\right)$} \\
\hline $1 / 28$ & $21: 40$ & -81.4 & 0.80 & -5.5 & -7.6 & -3.8 & $1 / 29$ & \multicolumn{7}{|c|}{ (Freeze continued, $\left.T a_{150 \max }=0.7\right)$} \\
\hline $1 / 30$ & $1: 25$ & -67.1 & 0.45 & -5.6 & -8.7 & -5.1 & $1 / 30$ & $10: 25$ & 83 & $295^{*}$ & $(0.9)^{*}$ & 3.8 & $9.5^{*}$ & 0.3 \\
\hline $1 / 31$ & $5: 55$ & -61.0 & 0.10 & -4.8 & -8.3 & -5.0 & $1 / 31$ & $10: 40$ & 80 & $307^{*}$ & $(1.2)^{*}$ & 8.1 & $11.8^{*}$ & 0.3 \\
\hline $2 / 04$ & $1: 45$ & -69.2 & 0.39 & -5.1 & -8.2 & -4.7 & $2 / 04$ & \multicolumn{7}{|c|}{ (Freeze continued, $T a_{150 \max }=2.9$ ) } \\
\hline
\end{tabular}

(Note) $T_{\mathrm{BOT}}:$ stem temperature at the bottom trunk.

$P_{\text {thaw }}$ : period from the start to the completion of thawing at the bottom trunk.

$\mathrm{Ta}_{150 \text { max }}$ : daily maximum air temperature at $150 \mathrm{~cm}$.

*: Interpolated Estimates from hourly data.

量が多くなるので，融解が遅れる方向に働くと考えられ る。しかし一方, 最低気温が低い日には晴れて風が弱い ことが多く, このような条件の日の翌朝は, 日射も強く 昇温が大きくなるので，逆㣂解速度を早める働きもあ る。最低気温時の株元樹幹部の温度とその部位の融解所 要時間, 融解終了時刻との関係については, 低温になる 日には融解が遅れる場合が多いが，明らかな関係は得ら れなかった。

\section{5 気象条件からの樹体の凍結の推定の可能性} 樹体の凍結開始は，株面表層の枝の中に小孔をあけて 熱電対を挿入して茎温を測る方法で比較的確実に検出で きるが，乙こでは，株頂部の凍結開始を気象条件から推 定するいくつかの簡易な方法について考察した。

方法 (1) 株頂部葉温 $T l_{\mathrm{TOP}}$ とその周辺の露点温度 $T d e w_{\text {TOP }}$ の観測值を用いる。

Fig. 7 亿示した破線は, 露点によって凍結開始温度が 変化する様子を簡略な形で表わしたものであるが，乙の 破線のように,

$$
\begin{aligned}
& T d e w_{\mathrm{TOP}} \geqq-1.9^{\circ} \mathrm{C} \text { のとき } T l_{\mathrm{TOP}} \leqq-2.1^{\circ} \mathrm{C} \\
& -1.9>T d e w_{\mathrm{TOP}} \geqq-3.5^{\circ} \mathrm{C} \text { のき } \\
& T l_{\mathrm{TOP}} \leqq T d e w_{\mathrm{TOP}}-0.2^{\circ} \mathrm{C} \\
& -3.5^{\circ} \mathrm{C}>T d e w_{\mathrm{TOP}} \text { のとき, } T l_{\mathrm{TOP}} \leqq-3.7^{\circ} \mathrm{C}
\end{aligned}
$$

となる最初の時刻を涷結開始時刻とする $(t f 1)$ 。

方法 (2) 高さ $150 \mathrm{~cm}$ の気温 $T a_{150}$, 純放射量 $R n$, 風速 $U_{150}$, 露点 $T d e w_{150}$ 少ら推定した $T l_{\mathrm{TOP}}, T d e w_{\mathrm{TOP}}$ の値を用いる。 $T l_{\mathrm{TOP}}, T d e w_{\mathrm{TOP}}$ は以下の式で求める。

$$
\begin{aligned}
& T l_{\mathrm{TOP}}=T a_{150}+A 1 R n U_{150}^{-0.5} \\
& T d e w_{\mathrm{TOP}}=A 2 \text { Tdew } w_{150}+A 3
\end{aligned}
$$

定数 $A 1$ には 0.0227 を, $A 2, A 3$ には晴天で弱風の夜間 のデータから直線回帰によって求めた $A 2=1.095, A 3=$ -0.61 を使用した。乙れを方法 (1) の判定条件にかけて
それを満たす時刻を凍結開始時刻の推定値 $(t f 2)$ とする。 また, 参考として以下の単純な方法についても調べて みた。

方法 (3) $T a_{150}$ が $-0.9^{\circ} \mathrm{C}$ (凍結開始時の平均值) 以 下になった時刻を凍結開始時刻の推定値 $(t f 3)$ とする。

方法 (4) $\quad T l_{\mathrm{TOP}}$ が $-2.8^{\circ} \mathrm{C}$ (凍結開始時の平均値) 以 下になった時刻を凍結開始時刻の推定値 $(t f 4)$ とする。

方法 (5) $\quad T l_{\mathrm{TOP}}$ の高さ $150 \mathrm{~cm}$ 気象条件加らの推定 值を使用する。 $T l_{\mathrm{TOP}}$ の推定値を(1) 式で求め, それが $-2.8^{\circ} \mathrm{C}$ になったときを凍結開始時刻の推定值 $(t f 5)$ とす る。

Table 2 亿凍結開始時の気象デー夕 (5 分間平均値) お よび上記の方法による推定時刻（tf1からtf5）を示す。 株頂部付近の水蒸気圧のデータは 2 月 3 日までの期間し か得られなかった。誤差をRMSE (平均 2 乗誤差の平方 根: Root Mean Square Error) でみると, $T l_{\text {TOP }}$ と $T d e w_{\text {TOP }}$ に推定值を用いる方法 (2) では 21 分である。 また，高さ $150 \mathrm{~cm}$ 気温だけを用いる方法 (3) の場合に は，葉温低下速度の絶対値 $|\Delta T l / \Delta t|$ が大きい日には 誤差は比較的小さいが，2月 10 日や 2 月 19 日のように $|\Delta T l / \Delta t|$ が小さな日には極端に大きくなる場合ああ り，T $a_{150}$ だけでは安定した推定は無理のようである。 $t f 4$ や tf 5 は葉温（あるいはその推定値）だけを用いた 推定であるが, RMSEはそれぞれ17 分, 22 分と比較的 小さかった。湿度デー夕を併用する方法 (1)，(2) は， RMSEが小さく極端な誤差を生じないので信頼性が高 はと考えられる。

このように株頂部の葉温と露点温度が実測あるいは推 定できれば冬季の樹体の凍結開始時刻の推定は可能であ る。晚霜期の涷結に関しては, 凍結開始温度が冬季と多 少異なることが考えられる。晚霜害が発生する静榣な快 
Table 2 Comparison of estimates for the freeze initiation at the top of tea bush using meteorological elements $(1 / 21-2 / 19,1989)$.

\begin{tabular}{|c|c|c|c|c|c|c|c|c|c|c|}
\hline \multicolumn{6}{|c|}{ Condition at freeze initiation } & \multicolumn{5}{|c|}{ Estimated time of freeze initiation (JST) and differences ( $\mathrm{min}$ ) } \\
\hline Date & $\begin{array}{l}\text { Time } \\
\text { (JST) }\end{array}$ & $\begin{array}{l}T l \\
\text { (C) }\end{array}$ & $\begin{array}{c}R n \\
\left(\mathrm{~W} / \mathrm{m}^{2}\right)\end{array}$ & $\begin{array}{c}U \\
(\mathrm{~m} / \mathrm{s})\end{array}$ & $\begin{array}{l}\Delta T l / \Delta t \\
(\mathrm{C} / \mathrm{min})\end{array}$ & $t f 1$ & $t f 2$ & $t f 3$ & $t f 4$ & $t f 5$ \\
\hline $1 / 21$ & 6:35 & -2.6 & -87 & 0.70 & $-5.9\left(\times 10^{-2}\right)$ & 6 & 年 & $6: 30(-5)$ & $6: 30(-5)$ & $-15)$ \\
\hline $1 / 24$ & 19:10 & -3.3 & -7 & 0.15 & -4.1 & $19: 00(-10)$ & $18: 40(-30)$ & $19: 05(-5)$ & $19: 00(-10)$ & $-40)$ \\
\hline $1 / 25$ & $19: 35$ & -2.1 & -6 & 0.72 & -0.5 & 19: & & & & \\
\hline $1 / 27$ & $17: 40$ & -3.5 & -9 & 0.79 & -5.5 & $17: 45$ & 18 & $17: 30($ & $17: 35(-5)$ & 17 \\
\hline $1 / 29$ & $17: 45$ & -3.5 & -6 & 0.25 & -7.3 & $17: 20$ & $17:$ & $17: 35(-$ & $17: 25(-20)$ & 17 \\
\hline $1 / 30$ & $17: 50$ & -3.5 & -7 & 0.30 & -7.1 & 20) & $5(-25)$ & 17: & $17: 35(-15)$ & $17: 25(-25)$ \\
\hline $2 / 03$ & $17: 40$ & -2.2 & -7 & 0.73 & -4.3 & $17: 40(0)$ & $(-5)$ & $17: 4$ & 18: & 17: \\
\hline $2 / 10$ & $23: 35$ & -1.8 & -3 & 1.27 & -1.9 & - & & & & \\
\hline $2 / 11$ & $18: 20$ & -2.5 & -5 & 0.12 & -5.3 & - & $18: 00($ & $19: 15($ & $18: 05(-15)$ & $18: 00(-20)$ \\
\hline $2 / 12$ & $18: 20$ & -2.8 & -80 & 0.13 & -6.6 & - & $18: 00(-20)$ & $18: 10(-10)$ & $18: 05(-15)$ & $18: 00(-20)$ \\
\hline & $19: 35$ & -2.0 & -4 & 0.54 & -2.4 & - & & $20: 20(t$ & $19: 1$ & $(-20)$ \\
\hline $2 / 1$ & $18: 20$ & -2.9 & 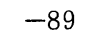 & 0.62 & -7.6 & - & $18: 20(0$ & $18: 35(+$ & $18: 10(-10)$ & $18: 20(0)$ \\
\hline $2 / 19$ & $18: 40$ & -2.6 & -86 & 0.53 & -1.7 & - & $18: 20(-20)$ & $19: 45(+65)$ & $18: 35(-5)$ & $18: 20(-20)$ \\
\hline \multicolumn{6}{|c|}{ Root mean square error ( $\mathrm{min}$ ) } & $(13.5)$ & 20.7 & 38.2 & 17.3 & 22.0 \\
\hline
\end{tabular}

(Note) $t f 1$ : Estimates using observed $T l$ and $T d e w_{\text {TOP. }}$.

tf 2 : Estimates using $R n, U_{150}, T a_{150}$ and $E a_{150}$.

tf 3 : Time when observed $T a_{150}<-0.9^{\circ} \mathrm{C}$.

tf 4 : Time when observed $\mathrm{Tl}<-2.8^{\circ} \mathrm{C}$.

tf 5 : Time when calculated $T l<-2.8^{\circ} \mathrm{C}$.

晴の夜間の凍結開始時刻の推定については，温度低下速 度が大きいので, 上式の凍結開始温度の設定をそのまま 用いても大きな時刻差にはならないと推察される。

次に，融解の推定についてであるが，葉身の融解時に は葉温が $0{ }^{\circ} \mathrm{C}$ 付近に維持される時間はほとんどなく, 周 りの環境変化によく追従することがわかったので, 葉温 の推移が推定できれば, 葉内の組織水点を仮定してその 温度まで昇温した時点で融解が開始・終了するとみなし て実用上問題はないと思われる。しかし, 株元地際部に ついては, 融解の開始から終了までの時間が長く, 融解 終了を推定するためには，樹体の凍結水分量を把握する 必要があると思われ，気象条件だけを用いて推定するの はかなり困難であると考えられる。

\section{4. まと め}

成木茶園における冬季・夜間の株周辺の温度分布と樹 体の凍結一融解の実態について調べた。株面上で最低温 度になる部位は，気流の影響を大きく受け，水平な場所 に植栽された株では，頂部から風下側肩部が最む低温に なることが多く，傾斜面の等高線うねでは谷側の肩部か ら裾部が最す低温になることが多かった。高さ $150 \mathrm{~cm}$ 気温之株頂部葉温との温度差 $\Delta T$ 之, 風速 $U_{150}$, 純放射 量 $R n$ との関係を, $\Delta T=A U_{150}^{-0.5} R n$ という式で表現し た場合，係数 $A$ の值は，突出枝が多い株面では 0.0227 $\left(\mathrm{J}^{-1}{ }^{\circ} \mathrm{C} \mathrm{m}^{2.5} \mathrm{~s}^{0.5}\right)$, 突出枝のない株面では 0.0320 となっ た。乙の式は, 晴天で風が弱く, $R n$ が約 $-90 \mathrm{~W} / \mathrm{m}^{2}$,
$U_{150}$ が $0.3 \mathrm{~m} / \mathrm{s}$ という条件では, $\Delta T$ が約 $-4{ }^{\circ} \mathrm{C}$ (突出枝 が多い)，約ー $5.5^{\circ} \mathrm{C}$ (突出枝なし)になることを示す。

1 月 -2 月下旬の観測期間中, 凍結が生じた夜には地 上部全体が涷結し, 凍結が全体に波及するのに要する時 間は約 20 分から 1 時間数十分で, 幼木よりあ長かった。 株頂部葉身の凍結開始温度之その周囲の露点温度との関 係は, 幼木で得られた関係と大差がなく, 凍結開始のメ カニズムは幼木と同様江最む低温となる部位の葉温とそ の周辺の露点温度によって決まると考えられた。すなわ ち，葉温が約 $-2{ }^{\circ} \mathrm{C}$ 以上であれば葉面に結露があっても 凍結せず, 葉の周囲の露点が約 $-2{ }^{\circ} \mathrm{C}$ 朽約” ${ }^{\circ} 4^{\circ} \mathrm{C}$ のき には葉温が露点付近になると凍結を始め, 葉の周囲の露 点がー $4{ }^{\circ} \mathrm{C}$ 以下の乾燥した夜では葉面に結露・結霜がな くても葉温が $-4{ }^{\circ} \mathrm{C}$ 付近で涷結を開始する，というとと である。

樹体の融解終了時刻は, 株元の樹幹部で最む遅くなっ た。最高気温が約 $3{ }^{\circ} \mathrm{C}$ 以下の日には，株面の葉層か瀜解 しても株元の樹幹部では凍結したまま翌日に続く状態が しばしば現われた。この状態では，乾燥・強風が伴う場 合には，水分欠乏ストレスが促進されると思われる。

冬季の凍結開始時刻を気象条件から推定する簡単な方 法について考察したとてろ, 株頂部葉温とその周囲の露 点データを用いると, RMS 誤差で約 20 分程度で推定で きるととがわかった。今後, 晚霜期における樹体の凍結 一融解現象の解明が望まれる。 


\section{謝辞}

本研究の観測にあたって測定場所の長期の使用をで快 諾いただいた, 当時の奈良県農業試験場茶業分場長 中 義次氏に深く感謝いたします。また，夜間観測の際には 茶業分場の職員の方々に便宜をはかっていただきました。 大阪府立大学農学部の鱧谷 憲氏には計測器関係でアド バイスをいただきました。乙てに感謝の意を表します。

\section{引用文献}

Anderson, J. A., Ashworth, A. N. and Davis, G. A., 1987: Nonbacterial ice nucleation in peach shoots. J. Amer. Soc. Hort. Sci., 112, 215218.

Andrews, P. K., Proebsting, Jr., E. L. and Gross, D. C., 1986: Ice nucleation and supercooling in freeze-sensitive peach and sweet cherry tissues. J. Amer. Soc. Hort. Sci., 111, 232-236.

Ashworth, E. N., Anderson, J. A., Davis, G. A. and Lightner, G. W., 1985: Ice formation in Prunus persica under field conditions. J. Amer. Soc. Hort. Sci., 110, 322-324.

馮 玉香, 羽生寿郎, 岡野通明, 中山敬一, 今 久, 1989: 作物の霜害に及ぼす水核活性細菌の影響につい て. 農業気象, 45, 7-12.

羽生寿郎, 松岡延浩, 今 久, 中山敬一, 1986 : 第 2 報 ダイズ苗葉面の乾湿が凍結温度に及ぼす影響. 農 業気象, 41, 331-335.

原田重雄, 中山 仰, 1961 : 凍結・融解の速度と寒害発 生との関係について. 茶業技術研究, 25, 11-15.

北浦 澄, 1967：晚霜による桑の涷結および被害に関す る研究. 蚕糸試験場報告, 22, 207-328.

牧野孝宏, 1985 : 茶樹新芽の霜害と水核活性細菌. 植物 防疫, 39, 14-17.
岡野通明, 羽生寿郎, 中山敬一, 今 久, 1989 : ダィ ズ苗葉の凍結温度への葉面露量の影響. 農業気象, 44, $275-280$.

劉 志民, 岡野通明, 中山敬一, 羽生寿郎, 今 久, 松岡延浩, 1991:水核活性細菌 Psudomonas syringae の水核活性に及ぼす培養温度の影響について. 農業気 象, 47, 11-14.

Sakai, A. and Larcher, W., 1987: Frost survival of plants. Springer-Verlag, Berlin, pp. 284.

鈴木義則, 青木正敏, 山本晴彦, 関谷次郎, 1985 : 茶樹 耐凍性の季節変動に関する研究 (2) 温度環境と凍結温 度の変化. 九州の農業気象, 第 21 号, 61-62.

高橋恒二, 青野英也, 田中静夫, 築瀬好充, 吉川 茂, 1961: 茶樹の凍霜害に関する研究, 降霜時の微細気象 之凍霜害の応急的ならびに栽培的防止法の研究. 東海 近畿農業試験場研究報告, 茶業部 8, 30-162.

Takaichi, M., 1989: Nature of frost damage distribution in tea gardens - a case study of the frost damage on 9 may 1988 in Nara Prefecture. Bull. Univ. Osaka Pref., Ser. B, 41, 51-60.

高市益行, 米谷 力, 1990 : 幼木茶園に打ける温度分布 之樹体の凍結. 農業気象, 46, 71-77.

鳥屋尾忠之, 家弓実行, 勝尾 清, 松下 繁, 1974：于 ヤの耐寒性の品種間差異之早期検定. 茶業試験場研究 報告, 9, 1-72.

山中捷一郎, 羽生寿郎, 西山 司, 中山敬一, 1982: 作 物の霜害と環境条件 第 1 報 ダイズ苗の霜害と凍結温 度之の関係. 農業気象, 38, 23-28.

築瀬好充, 青野英也, 杉井四郎, 1974 : 茶樹の越冬傷害 の発生機構とその防止法. 茶業試験場研究報告, 10, $1-90$.

吉田静夫, 酒井 昭, 1967 ：植物の凍害に打よぼす融解 速度の影響 I 急速融解の害. 低温科学, 生物篇, 25, $23-31$. 